\title{
Carbon family nanomaterials - new applications and technologies
}

\author{
Petra Roupcova ${ }^{a}$, Karel Klouda ${ }^{a}$, Paula Brandeburova ${ }^{\mathrm{b}}$, Rastislav Sipos ${ }^{\mathrm{c}}$, \\ Jan Hives $^{\mathrm{d}}$, Miroslav Gal ${ }^{\mathrm{d}}$, Tomas Mackulak ${ }^{\mathrm{b}}$, Michaela Skrizovska ${ }^{\mathrm{a}}$, Lenka Kissikova ${ }^{\mathrm{a}}$ \\ ${ }^{a}$ VSB - TU Ostrava, Faculty of Safety Engineering, Lumirova 13, 70030 Ostrava - Vyskovice \\ ${ }^{b}$ Department of Environmental Engineering, Faculty of Chemical and Food Technology, \\ Slovak University of Technology, Radlinskeho 9, 812 37, Bratislava \\ ${ }^{'}$ Department of Inorganic Chemistry, Faculty of Chemical and Food Technology, \\ Slovak University of Technology, Radlinskeho 9, 812 37, Bratislava \\ ${ }^{d}$ Department of Inorganic Technology, Faculty of Chemical and Food Technology, \\ Slovak University of Technology, Radlinskeho 9, 812 37, Bratislava \\ petra.roupcova@vsb.cz
}

\begin{abstract}
Research on carbon-based nanomaterials (CBNMs) and their development is one of the major scientific disciplines of the last century. This is mainly because of their unique properties which can lead to improvements in industrial technology or new medical applications. Therefore, it is necessary to examine their properties such as shape, size, chemical composition, density, toxicity, etc. This article focuses on the general characteristics of nanomaterials (NMs) and their behavior when entering the environment (water and soil). In addition, it presents individual members of the graphene family including porous ecological carbon (biochar). The article mainly deals with the new potential technologies of CBNMs considering their possible toxic and genotoxic effects. This review also highlights the latest developments in the application of self-propelled micromotors for green chemistry applications. Finally, it points to the potential biomedical applications of CBNMs.
\end{abstract}

Keywords: biochar, ecology, biosensors, graphene family, nanostructures, micromotors

\section{Introduction}

With the intensive use of nanoparticles, it has been shown that many of them may have negative effect on human health and the environment. Manufactured nanoparticles are likely to be more damaging than particulate matter of the same materials but with conventional size as they, for example, penetrate deeper into the lungs due to their 'nano' size (Liu et al., 2014). There is still a lack of information about the interactions of nanoparticles with biological systems; therefore, the research in this field is essential (Bakand et al., 2012).

NMs are an innovative science discipline that has grown steadily and has gained interest of the general

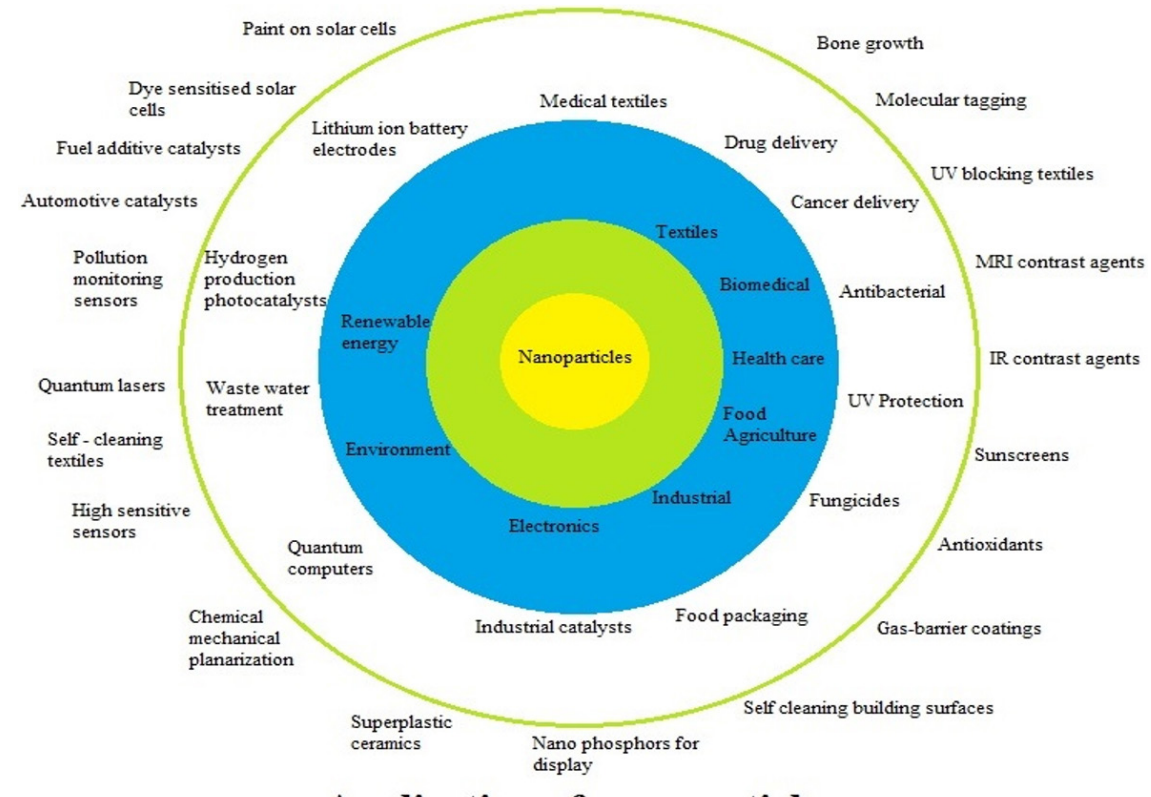

Application of nanoparticles

Fig. 1. Potential applications of carbon-based nanomaterials (Garcia, 2017). 
public due to various reasons such as the high number of new materials produced by synthesis, improved techniques for their characterization and diverse applications across a wide range of disciplines (Fig. 1).

This article describes the members of the graphene family and provides their brief characteristics. It also deals with new potential applications of CBNMs, such as graphene oxide (GO), graphene, and their other hybrid modifications with other materials - biochar, composites/oxides of metals etc. The review highlights the last development in the application of self-propelled micromotors and the treatment of cancer considering toxicity and genotoxicity of graphene nanoparticles.

\section{Characteristics of NMs and CBNMs}

\section{Nanoparticles and their general characteristics}

Each type of nanoparticle, in addition to its dimension within 1 to $100 \mathrm{~nm}$, can be described by the following characteristics $(\mathrm{Ju}, 2018)$ :

- chemical composition,

- functional groups on the surface (hydrophilicity, lipophilicity),

- shape,

- distribution layout of particles,

- density,

- crystalline structure,

- zeta potential,

- ability of aggregation, agglomeration, and sedimentation (Terrones et al., 2012).

With these properties they enter the external environment (Loureiro et al., 2018). In air, the so-called abiotic impact factor takes effect; it may comprise temperature, humidity, salinity, solar radiation, smog, pollutants of inorganic and organic origin etc. In an aqueous medium, physico-chemical characteristics of the aqueous phase have to be considered: ground water, surface water, river and sea water, temperature, $\mathrm{pH}$, ionic strength, concentration ions, concentration of natural organic matter, and composition of the sediment (Terrones et al., 2012).

Surface water may be considered as one of the main points of entry, facilitating dispersion of NMs in the environment and establishing a link to other parts of environment such as soil, sediment, and biota. Factors influencing the fate of nanoparticles in an aqueous medium are (Baun et al., 2017; Freixa et al., 2018):

- surface hydrophilicity (water solubility),

- hydrolysis, redox reactions,

- adsorption (plays an important role in C-nanoparticles) (Kyzas et al., 2014),

- aggregation,

- hetero-aggregation,

- presence of aquatic organisms (bacteria, algae, protozoa, plankton, larvae, fish, etc.),

- sedimentation rate,

- composition of sediment and its reactivity (adsorption, reduction by phytoextracts and biological material, presence of soil organic matter, presence of polyaromatic hydrocarbons pollutants, hetero-aggregation, etc.) (Kyzas et al., 2014) see Figure 2.

Also in soil, the physico-chemical characteristics have to be taken into account. The solid phase contains minerals of different grains (considering the content of the $0.01 \mathrm{~mm}$ fraction) and organic soil

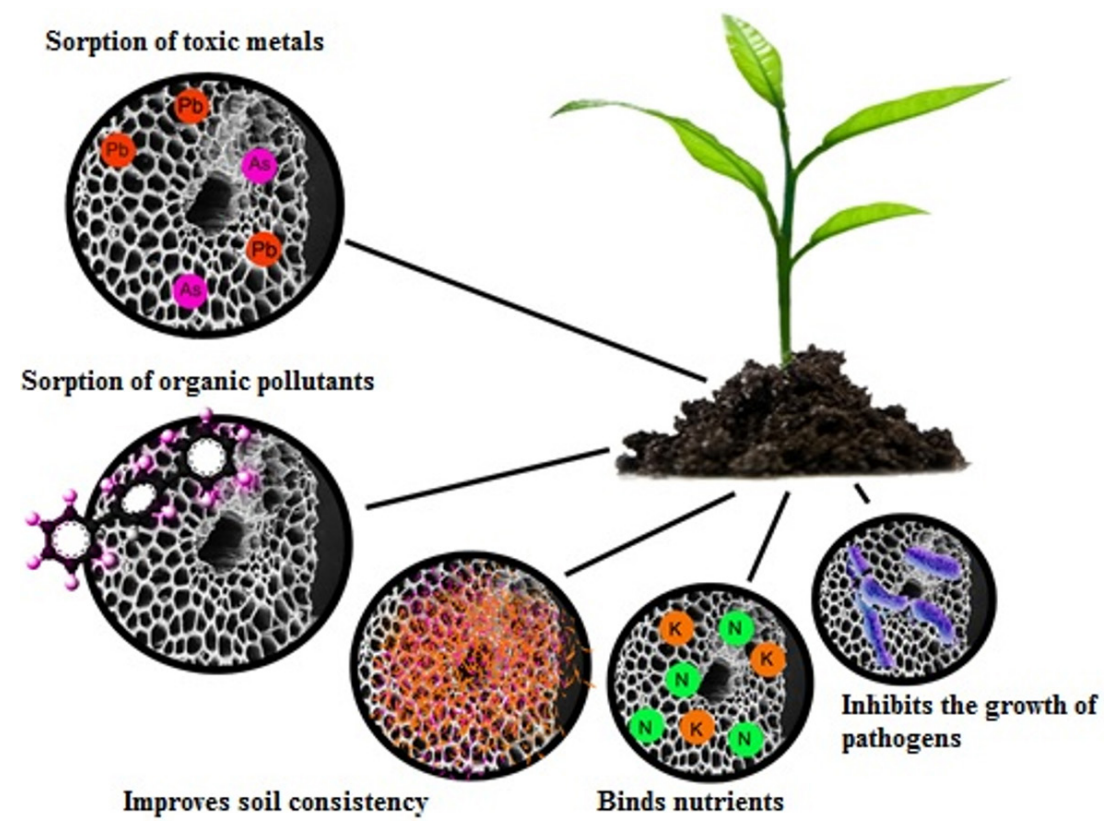

Fig. 2. Effect of biochar in soil. 
components (Theng and Yuan, 2008). The basis of this matter are humic substances, i.e. mixtures of polydisperse compounds with high molecular weight and aromatic and aliphatic parts with functional groups $-\mathrm{COOH},-\mathrm{OH}$, phenolic $-\mathrm{OH}$, $-\mathrm{NH}_{2}$, N-heterocycles, etc. (Theng and Yuan, 2008). Basic partitioning of humic substances is according to solubility in relation to $\mathrm{pH}$ : fulvic acids are soluble in water, humic acids in alkaline environment, and humine is insoluble (Theng and Yuan, 2008). Soil water, also known as the soil solution, can contain fulminic acids, phytoextracts and substances with polyphenol structures, glycides, ions etc. Thanks to the soil solution, the influence caused by nanoparticles is similar as in case of an aqueous medium.

Main factors influencing the fate of nanoparticles in the soil environment are (Loureiro et al., 2018;

Freixa et al., 2018):

- surface hydrophilicity and lipophilicity,

- hydrolysis,

- reduction (green reduction by substances from phytoextracts),

- hetero-aggregation (clay soils),

- presence of soil micro-organisms and animals (bacteria, larvae, earthworms, etc.),

- adsorption ( $\pi$-binding interactions, hydrogen bonds, electrostatic interaction, acid-base interaction).

Environmental behavior and effects of CBNMs in natural aquatic systems are related to their ability to interact and aggregate, creating clusters exhibiting colloidal behavior. Despite the virtual water insolubility of individual CNM molecules, the formed aggregates are stable under certain environmental conditions. To put it simply, transport and fate of carbon nanoparticles can be divided into three main possible effects that can exist independently, intermingle or coexist in synergy (Freixa et al., 2018):

- modification of nanoparticles (adsorption plays the main role here),

- change in the composition of nanoparticles (mutual reaction of functional groups with organic or inorganic substances),

- degradation of nanoparticles (physical, chemical, or biological) (Zhao et al., 2014).

The question remains as to how the future fate, transport, and mainly toxicity of these nanoparticles changes after degradation or the change of functional groups on their modified surface. One of the least inert NMs to the environment seems to be graphene oxide (Zhao et al., 2014). Its strong adsorption capacity, propensity to biological reduction, reactivity of its functional groups on the carbon skeleton (Park and Yan, 2013; Shanmugharaj et al., 2013), and lastly the ease of photochemical degradation (Shanmugharaj et al., 2013) have already been described. Interaction of GO and graphene with cell membrane can lead to indirect toxicity, i.e. blocking of ions and gases exchange. Their internalization into cells can cause oxidative stress, DNA damage as well as mitochondrial malfunction (Zhao et al., 2014).

\section{Graphene based NMs}

Graphite is a natural laminated compound with $\mathrm{sp}^{2}$ hybridization and the distance between the layers of 338 pm (Seabra et al., 2014; Lin et al., 2016). The plane graphite layer is formed by six-C-cycles; among other things, it is possible to prepare a series of compounds with carbon skeleton from this natural compound. Graphite can be intercalated, fluorinated, oxidized or exfoliated. Intercalation allows the formation of an inter-layer space, into which, e.g. alkali metals or volatile halogens can be intercalated. The interchange force is the exchange of electrons between the carbon layer and the intercalated substance (Lin et al., 2016). The so-called graphene family includes: fluorine graphite (CF), GO, reduced graphene oxide (rGO), graphene, multilayer graphene, single and multi-walled carbon nanotubes (SWCNT, MWCNT), fullerenes (ex. $\mathrm{C}_{60}$ ), carbon quantum dots (CQDs) and porous carbon (biochar). Graphite exfoliation (spherical grinding, sonication, dynamic fluid shear forces) results in the formation of graphene (one plane carbon layer) with a honeycomb structure: -C- hexagons in a plane (Zhao et al., 2014). Under certain conditions it can be doped, and therefore it is possible to partially replace carbon for $\mathrm{N}, \mathrm{S}, \mathrm{B}$, or $\mathrm{P}$ (Hu and Sun, (2013).

GO is prepared by graphite oxidation by strong oxidizing reagents; it serves as a precursor for the chemical preparation of graphene (Zhang et al., 2011). Its carbon skeleton contains the main functional groups such as carboxyl-, carbonyl-, epoxide-, etheric- and hydroxy-groups. Using the functional groups, GO functionalization can be realized chemically e.g. by amidation, esterification, or substitution (Kyzas et al., 2014). GO can also be noncovalently functionalized e.g. with biomolecules, where $\pi-\pi$, cation- $\pi$, anion- $\pi$, and hydrogen bridges interactions are formed. It also serves as a deposit for nanoparticles of metals and their oxides (Kyzas et al., 2014). It can be applied as a composite in a series of polymers. All of this affects its application options. Non-covalent interactions are used in the preparation of composite biopolymers (Yoo et al., 2014) using the adsorption and absorptive ability of GO (Kyzas et al. 2014; Chabot et al., 2014; Fakhri, 2017). Graphene oxide has unique characteristics 
such as electronic, magnetic, optical, and thermal (Xu et al., 2013; Paulchamy et al., 2015), it is also an electrical insulation material, hygroscopic and dispersible (Paulchamy et al., 2015). By selecting a processing technology, various modifications of GO in suspension can be obtained, such as quantum dots (Chien et al., 2012) or films applied in biology (Paredes et al., 2013), electrical applications (Zhu et al., 2012) optics (Xu et al., 2013) and biomedicine (Fernandez-Merino et al., 2010; Sanchez et al., 2012); Zhang et al., 2016), as well as fibers (Shahil and Balandin, 2012). Graphene-based NMs also belong to the one of the most promising modifications of electrode surfaces resulting in impressive properties of advanced electrochemical sensors in biomedical application (Stanković et al., 2017; Svítková et al., 2016).

The publications concerning the oxidation of graphite with a view to obtain GO mostly state that a method was used bearing the names of particular authors: Hofmann $\left(\mathrm{HNO}_{3}, \mathrm{KClO}_{3}\right)$, Tour $\left(\mathrm{P}_{2} \mathrm{O}_{5}\right.$, $\mathrm{KMnO}_{4}$ ), Hummers $\left(\mathrm{NaNO}_{3}, \mathrm{KMnO}_{4}\right)$ (Seabra et al., 2014). In all these methods the reactive environment is concentrated sulphuric acid (Chng and Pumera, 2013).

After oxidation, GO has on its carbon skeleton the above mentioned oxygen functional groups that can be reduced by a number of agents (methods) affecting the $\mathrm{C} / \mathrm{O}$ ratio and the diversity in reduced groups; e.g. hydrazine reduces preferably epoxy groups, $\mathrm{NaBH}_{4}$ reduces $-\mathrm{C}=\mathrm{O}$ and $-\mathrm{COOH}$. The most commonly used reducing agents are $\mathrm{NH}_{2} \mathrm{NH}_{2}$ (Ramesha et al., 2011), $\mathrm{NaBH}_{4}$ (Chua and Pumera 2013), metal-acid (Agharkar et al. 2014), HI, polyphenols (chinons), polysaccharides, "green" reduction - plant extracts (Agharkar et al. 2014; Roupcova and Klouda, 2017), ascorbic acid (Paredes et al., 2013), $\mathrm{FeSO}_{4}$, bacteria (Wang et al., 2011); the methods used include: thermal, hydrothermal and electrochemical reduction (Chua and Pumera, 2013). Partially reduced graphene oxide is marked rGO and is used in a variety of applications, mostly as the combination of $\mathrm{GO} / \mathrm{rGO}$. Total reduction of oxygen-containing groups provides graphene (Chng and Pumera, 2013).

Current publications include articles describing common oxidation of graphite with fullerene $\left(\mathrm{C}_{60}\right)$, $\mathrm{CF}$, or biochar to create a unique hybrid product with different weight ratios (Roupcova et al., 2017; Zhang et al., 2009). In addition, these syntheses have been enriched with the combined oxidation of graphite with MWCNT (Roupcova and Klouda, 2017).

Fullerenes are wide closed-cage carbon clusters with extraordinary properties (Notariani et. al., 2016). They were discovered in 1985 and belong to the group of carbon allotropes $\left(3^{\text {rd }}\right)$ after graphite $\left(1^{\text {st }}\right.$ ) and diamond $\left(2^{\text {nd }}\right)$. Fullerene $\mathrm{C}_{60}$ (so far the most stable form) named after Buchmister Fuller, who built buildings in the shape of domes resembling a soccer ball (bucky ball) (Sharma et al., 2015). Many techniques to synthesize fullerenes have been introduced: laser ablation of graphite + He; AC arc discharge of graphite + gas (He, Ar), combustion of benzene $\left(\mathrm{O}_{2}\right)$, chemical synthesis and introduction of dopants inside the structure (Lee et. al, 2002; Saunders et al., 1994).

Fullerenes possess excellent stability, large specific surface area, superior electrical conductivity, and individual three-dimensional structure. One of the major applications of fullerenes is photocatalysts (pollutants degradation, production of hydrogen, antibacterial, water disinfection) (Pan et. al., 2020). From the biomedical applications, fullerenes are known as antioxidants, drug delivery and antiviral agents (against flu viruses, herpes simplex virus (HSV), human immunodeficiency virus (HIV) and cytomegalovirus (CMV)) (Pochkaeva et. al., 2020).

The structure, shape and the emergence of carbon nanotubes (CNT) can be pictured as a graphene plane rolled in the direction of two possible vectors. This will arrange the tubes with mutual arrangements of six-member-C-circles into the structure of: chair, zigzag, or chiral. According to the number of layers, the carbon tubes can be divided into singlewalled and multi-walled types (Lee et al., 2012). The basic preparation consists of the deposition of chemical vapor using the CVD method at high temperatures $\left(500-900{ }^{\circ} \mathrm{C}\right)$, depending on the organic material and the catalysis by various metals (Lee et al., 2012). Rolling of the carbon plates can also be carried out under normal laboratory conditions from graphene oxide in a strongly acidic environment and in the presence of ferrocene aldehyde (Calvaresi et al., 2013). The surface of carbon nanotubes can be functionalized to form covalent bonds between the surface of the nanotubes and the substituent, non-covalent ones by modification with a macromolecule (hybrid, composite), or by physical adsorption of molecules on the surface of the nanotube (Calvaresi et al., 2013). Reactions that allow covalent bonding on the nanotube include:

- oxidation (in solution, gaseous phase, plasma),

- halogenation (iodination, bromination, chlorination, fluorination by reaction with $\mathrm{BrF}_{5}$, $\mathrm{XeF}_{2}$ ),

- reaction with diazonium salts $\left(\mathrm{ArN}^{2+}\right)$ (Calvaresi et al., 2013).

Non-covalent modification of nanotubes is predominantly provided by $\pi-\pi$ interactions, $\pi$-stacking, electron transfer, hydrophobic interaction with pyrene derivatives, polymer composites, or 
composites with biological molecules, DNA, proteins, etc. This type of reaction may include graphene rGO-MWGNT composites. Published preparations of these composites comprise mixing of graphene oxide and MWCNT in a certain weight ratio; sonication and subsequent reduction by hydrazine (Woo et al., 2012), ferrous sulfate (Kabiri et al., 2014), ascorbic acid (Chartarrayawadee et al., 2013), or i-propanol under $\gamma$-radiation ${ }^{60} \mathrm{Co}$ (Sun et al., 2014).

The thus-prepared composites, rGO-MWCNT, can be used in super-capacitors (Sun et al., 2014) or, after morphological treatment, as an ideal adsorbent for organic substances, especially oils (Kabiri et al., 2014). Modern applications of carbon nanotubes utilize their ability to behave as a unique nano-reactor. In such nano-reactor, i.e. within the carbon nanotubes, the concentration of chemical reactants increases thereby increasing the reaction rate; the charge transfer effects are reflected in the reduction of free activation energy, and the arrangement of the molecules allows the reaction to be directed in the desired direction (Miners et al., 2016). Electron transmission also affects catalytic activity. Metal nanoparticles of Ni, Fe, Pd, Pt, Ru, Co, and Cu (Miners et al., 2016; Wang et al., 2012) are often used as catalysts, adsorbed on the carbon surface (Miners et al., 2016). Several hydrogenation reactions, synthetic gas conversions, ammonia synthesis or decomposition, oxidation reaction, etc. (Miners et al., 2016) have been realized in this way.

GO, graphene, hybrid compounds, composites, and porous carbon (biochar) have the following applications:

- adsorption materials (absorbents) for metal ions, organic pollutants in waste water treatment plants (WWTP) (Gopalakrishnan et al., 2018; Wei et al., 2018),

- sensors (of gases, metals, biomolecules) (Ju, 2018),

- energy accumulation - electrode material for super-capacitors, Li-ion batteries, solar collectors,

- hybrid compounds and composites - magnetic composites, ternary composites,

- C-catalysts,

- $\mathrm{C}-\mathrm{M}, \mathrm{C}-\mathrm{MO}_{\mathrm{x}}$-catalysts,

- photochemical catalysts $\left(\mathrm{C}-\mathrm{TiO}_{2}\right)$,

- environmental applications (Oladipo and Ifebajo, 2018),

- construction, diagnostics (Roupcova, 2017).

CQDs belong to nanostructures consisting of Catoms and their size is below $10 \mathrm{~nm}$ (Molaei, 2019a, 2019b). They are functionalized with biomolecules or organic substances (Molaei, 2020) and they are characterized by (Lim et al., 2015; Zuo et al., 2016):
- fluorescence emission,

- solubility in water,

- preparation simplicity,

- low toxicity,

- biocompatibility,

- chemical inertness,

- functionalization.

CQDs have found many applications in various areas such as bioimaging (both in vivo/vitro) (Jamieson et al., 2007), drug and gene delivery, solar energy, sensors, solar energy conversion, photoelectrochemical (PEC) cells, solar cells, etc. They can be considered as a substituent for semiconductior quantum dots (QDTs) due to the characteristics mentioned above as in comparison to semiconductor quantum dots (QDs), they can be considered as alternatives in solar energy conversion applications (Molaei, 2020).

\section{Biochar}

Biochar is also ranked among carbon NMs because it is a porous carbonaceous material. Biochar, or bio-charcoal, is the product of waste pyrolysis after biomass fermentation (Zhu et al., 2012; Weber and Quicker, 2018). Biomass or wastes, from which biochar is most often produced, can come from various sources, such as cow and pig manure, straw, fruit skins, rice, peanuts, maize, soy, wood waste, sludge from WWTP etc. (see Figure 3). After the biomass fermentation process, which aims to produce biogas, so called digestate remains, mostly containing a solid portion and a liquid portion, is left (Zhu et al., 2012; Weber and Quicker, 2018). The separated solid material can be treated by pyrolysis at $300-600{ }^{\circ} \mathrm{C}$ with restricted air access or without it. Decomposition temperature can be reduced by hydrothermal pyrolysis (wet pyrolysis), where the main ongoing reaction is hydrolysis of hemicellulose, cellulose and lignin and subsequent decarboxylation, dehydrogenation, aromatization and condensation (Zhu et al., 2012). Pyrolysis or hydrothermal pyrolysis yields a porous carbonaceous material with a compact hydrophobic core of a predominantly aromatic structure and a shell exhibiting hydrophilic and chemically active properties (surface groups $-\mathrm{OH},-\mathrm{C}=\mathrm{O},-\mathrm{C}-\mathrm{O}-\mathrm{C}-$, - $\mathrm{COOH}$ ) (Wei et al., 2018). Surface of biochar can be reduced (ascorbic acid), oxidized (hydrogen peroxide) or further modified, and thereby its properties can be altered (Roupcova, 2017).

The Biochar Journal (Schmidt and Wilson, 2014) published 55 examples of biochar application with a precondition for commercialization. In addition to its specific use (Yao and Wu, 2015; Zhang et al., 2014), such as a heterogeneous catalyst with wide application and energy conversion/storage as a super- 


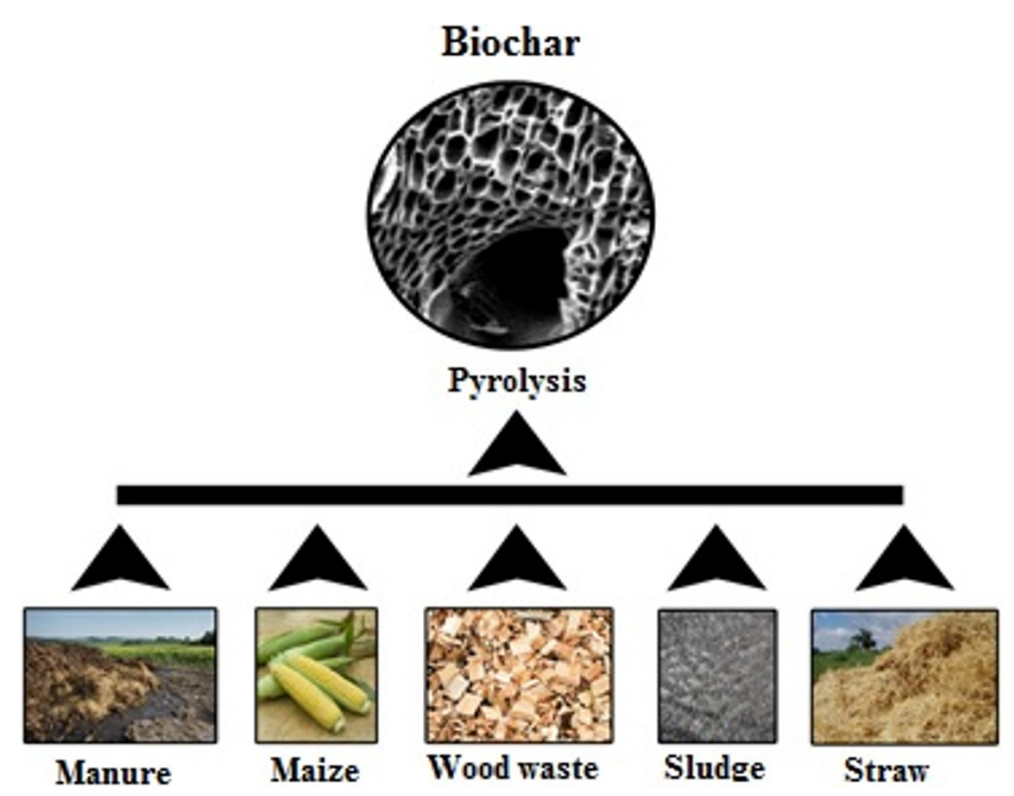

Fig. 3. Most common substrates for biochar production.

capacitor or Li-batteries, the main application of biochar is in soil engineering and as an adsorbent for various inorganic and organic pollutants, both in water and soil - see below. In relation to agriculture (soil), biochar provides the following benefits (Krishnakumar et al., 2014; Roupcova et al., 2017):

- increased water capacity of soil;

- increased biomass production;

- increased pH of soil;

- reduced toxicity of aluminium;

- reduces tensile strength of soil;

- changed (supported) microbial activity;

- reduced emissions of $\mathrm{CO}_{2}, \mathrm{~N}_{2} \mathrm{O}, \mathrm{CH}_{4}$ from soil, absorbs organic and inorganic compounds (Krishnakumar et al., 2014; Roupcova et al., 2017).

Applications of biochar are very diverse, ranging from heat and power production, flue gas cleaning, metallurgical applications, agriculture and animal husbandry, building material, to medical use. In an attempt to reduce greenhouse gas emissions, it has gained increasing popularity in the last years as a replacement for fossil carbon carriers in several of these applications (Weber and Quicker, 2018) due to its ability to absorb both inorganic substances (ions of heavy metals) and organic contaminants in an aqueous medium and in soil preventing or reducing the entry of undesirable substances in the plants (Krishnakumar et al., 2014).

\section{NMs toxicity and genotoxicity}

The science which deals with toxicity and effects of artificially created nano-structures and mechanisms to living organisms is called nano-toxicology (Durnev and Lapitskaya, 2013). Toxicity of nanoparticles is affected by several factors such as the quantity and size of particles, their concentration, specific surface, charge, shape, structure, reactivity, or solubility; therefore, their physical and chemical properties should be considered in the analysis of nanoparticles (Freixa et al., 2018; Borm et al., 2006). It is rather complicated to examine the toxicity of NMs because they behave differently in various environments and change their structure and composition. Therefore, to determine their toxicity, various studies have to be conducted to examine their contact with organisms (dermal, oral, or other means), and their effects (Freixa et al., 2018). To examine the toxicity, various analytical techniques are needed; it is not possible to analyze it only by one single analytical technique.

Various methods are used to determine the toxicity of NMs: cell toxicity (Tabei et al., 2019), genotoxicity (Martínez-Paz et al., 2019), toxicity of microorganisms (Chen et. al, 2019), test on larvae (Moon et. al, 2019). Standardized methods of NMs ecotoxicity include tests on:

- higher green plants - e.g. Sinapis Alba L. (white mustard) (OECD 208/1984) Terrestrial plants, growth test, methodical instruction of the Department of Waste of the Ministry of the Environment of the Czech Republic to determine the ecotoxicity of waste,

- invertebrates - e.g. Daphnia manga (pearl mussel) (Gao et al., 2018),

- vertebrates - e.g. Brachydario rerio (Striped Danio) (Jia et al., 2019),

- autotrophic unicellular green algae - e.g. Desmodesmus subspicatus (Nam et al., 2018).

Another reason why their toxicity is relatively unexplored is that most of the analytical methods are destructive, and so it is not possible to re-use the 
samples (Brandeburova et al., 2017; Mackulak et al., 2016; Tiede et al., 2008). Particles are made of the same material but their toxicity varies with different sizes. The material in form of nanoparticles is more toxic than the larger particles that can still be breathed in. Nanoparticles can be moved from the place of accumulation via nasal vessels up to the brain and gain access to blood and other organs; phagocytosis is not able to stop them. Nanoparticles of very small dimensions, smaller than some molecules, can bind to larger molecules and then modify the protein structures (Donaldson et al., 2004; Ghika et al., 2018). In addition to the size of nanoparticles and their surface, an important factor in their toxicity is also oxidative stress causing inflammation and genotoxicity (Ghika et al., 2018; Hussain et al., 2009).

\section{Ecotoxicity of NMs of the graphene family}

A whole series of specialized studies has been devoted to the toxic effects of NMs from the graphene group. Detailed research studies (Seabra et al., 2014; Guo and Mei, 2014; Jastrebska et al., 2012) summarize the contemporary findings concerning the toxic effects and possible mechanisms of toxicity. While their conclusions agree that graphene, graphene oxide, and reduced graphene oxide have toxic effects both in the in vitro and in the in vivo tests (Roupcova, 2017), the interpreted toxicity results vary and depend on many factors, such as the physical form of the tested substance, method of its preparation (contamination during chemical preparation or during reduction), environment where the toxicity test was carried out, or biological system the tests were performed on (bacteria, green algae, nematodes, crustaceans, mammalian cells, etc.) (Roupcova, 2017). For example, the following data have been published concerning GO toxicity in an aqueous medium (Roupcova et al., 2016):

- toxicity to crustaceans Amphibalanus Amphitrite (Mesaric et al., 2013),

- toxicity to microbiological community in effluents (Ahmed and Rodrigues, 2013),

- non-toxicity against bacterium Shewanella oneidensis (Wang et al., 2011),

- slight toxicity to embryos of Zebra Danio (Danio rerio) (Chen et al., 2012),

- non-toxicity to embryos of Zebra Danio (Danio rerio) (Zhou et al., 2012),

- either toxic or non-toxic to field bean seeds (Vicia faba) (Anjum et al., 2014).

From this summary, the disunity of results can be seen. The interaction with live systems is influenced by both the concentration of the test substance and the functional groups on its surface, particle size, exposure time, type of exposed cells (Seabra et al.,
2014), and, in our opinion, also purity of the test substance. All these variables affect the results of the toxicity tests.

For example, phytotoxicity of graphene and GO was analyzed by tests carried out with seeds and germination plants of tomato, headed cabbage, red spinach and lettuce (Roupcova et al., 2016; Begum et al., 2011). Concentrations of $0,500 \mathrm{mg} / 1,1000 \mathrm{mg} / \mathrm{l}$, and $2000 \mathrm{mg} / \mathrm{l}$ were tested and the exposure time was 20 days. Results of the tests showed significant reduction of growth and the number and size of leaves at the highest concentration in almost all products, with the exception of lettuce; at the same time, there increase in the production of reactive oxygen species (ROS) and of the necrotic symptoms was observed (Roupcova et al., 2016; Begum et al., 2011).

Similar tests were conducted by Anjum et al. with field bean seeds (Vicia faba). The seeds were exposed to different concentrations of GO suspension (suspension contained particles of $0.5-5 \mu \mathrm{m}$ created from a simple GO bi-layer) in the concentration range of $0-1600 \mathrm{mg} / \mathrm{l}$. The study revealed both positive and negative impact on the growth parameters (Anjum et al., 2014). Positive impact has been determined with GO concentrations of 400 and $800 \mathrm{mg} / 1$. For other concentrations, either lower or higher, the impact on the bean growth parameters was negative. The negative effect was indicated by the drop of growth parameters, increased activity of enzymes decomposing hydrogen peroxide, increased level of electrolyte leak (damaged stability of cell membranes), and finally by increased levels of hydrogen peroxide and lipids and proteins oxidation. These results demonstrate the complexity of phytotoxicity results interpretation. A question remains why the specified GO concentrations optimized the physiological process of germination and growth (Hussain et al., 2009; Lanwani et al., 2016).

\section{Applications of NMs}

\section{Environmental applications of CBNMs}

Many hazardous pollutants from industry enter the environment every year. To help protect the environment and humans, adequate safety management is required employing chemical, biological or physical treatment (Jurado-Sanchez and Wang, 2018; Tratnyek and Johnson, 2006).

Micromotors present a brand new paradigm for actual time environmental monitoring with huge promise for detection of sudden changes and possible threats or for monitoring remediation processes or hardly accessible environments. One effective strategy depends on the changes in the floating behavior of catalytic self-propelled micromotors 
when hazardous chemicals are present (JuradoSanchez and Wang, 2018; Sen et al., 2009).

\section{Use of micromotors for adsorption}

Adhesion of atoms, molecules or ions from a liquid, dissolved solid or gas to a surface is called adsorption. Concerning micromotors and the environment, research has been directed towards the proposal of micromotors functionalized with proper (bio)-ligands or composed of activated carbon or graphene. A great part of attention has been paid to dynamic oil removal using micromotors as an effective way to encounter petroleum drops (Jurado-Sanchez and Wang, 2018). For example, hydrophobic graphene/Pt tubular micromotors, made by rolling together with wax-printed sheets, were successfully tested for collecting lubricants from water samples. The high surface-to-volume ratio combined with graphene along with selfpropelled micromotor motion offers friendly conditions to collect lubricant droplets occurring in water through its hydrophobic interactions (Baptista-Pires et al., 2018).

Graphene is the most used allotrope of carbon for adsorptive removal of pollutants. For example, reduced graphene oxide coated silica/Pt Janus magnetic self-propelled micromotors show enhanced removal of persistent organic pollutants (triclosan and polybrominated diphenyl ethers) from water. Micromotors can be repeatedly used in four cycles in sequence without any difference in their adsorption characteristics (Orozco et al., 2016).

\section{Pollutant degradation micromotors}

Progressive oxidation processes play an important role in the chemical treatment removing organic and inorganic pollutants in water by oxidation through chemical reactions with ozone $\left(\mathrm{O}_{3}\right)$, hydrogen peroxide $\left(\mathrm{H}_{2} \mathrm{O}_{2}\right)$, hydroxyl radicals $(. \mathrm{OH})$ or UV light. Peroxide driven self-propelled micromotors provide a new dimension to progres- sive pollutant removal because peroxide behaves as a strong oxidizing agent broadly used by environmental communities for the degradation of dangerous organic substances. The micromotor motion enables faster contact of the pollutants and active reactants, developing in more dynamic degradation processes that can be compared to static opposites (Jurado-Sanchez and Wang, 2018). A short overview of CBNMs used as self-propelled micromotors is given in Table 1 .

\section{CBNMs and their applications in medicine}

The development of different NMs for diagnosis and therapy caused NMs to become an interesting and important area of biomedical research. Due to the high toxicity and side effects of the use of traditional chemotherapy in cancer, scientists are working on the development of alternative therapeutic technologies (Roacho Perez et al., 2018). The above mentioned NMs can assist in the monitoring of disease progress and treatment efficacy, recognize blood type of the patient, or the type of tissue at transplantation ( $\mathrm{Li}$ et al., 2018). One of the main advantages of these substances is their non-invasive use as a diagnostic tool. Another new and exciting feature is the multi-modal use of one sensor formed from NMs. This allows for a better and more accurate understanding of the in vivo action (Wang et al., 2017). Moreover, the connection of diagnosis and treatment in one system provides new possibilities in the treatment of diseases such as cancer. This type of treatment is called teranostics. When applying a modified nanomaterial in various imaging techniques and treatment possibilities, higher therapeutic efficacy can be achieved (Barreto et al., 2011).

\section{NMs characteristics in cancer treatment}

The prerequisite of successful use of NMs in vivo as well as in vitro is their correct synthesis. A particle that has the right size, surface, or polarity has to

Tab. 1. Summary of carbon based micromotors for potential environmental applications.

\begin{tabular}{lll}
\hline Motor & Pollutant & Reference \\
\hline $\begin{array}{l}\text { Removal of pollutants by adsorption } \\
\text { Activated carbon/Pt Janus micromotors }\end{array}$ & $\begin{array}{l}\text { Heavy metals, explosives, nerve } \\
\text { agents, azo dyes }\end{array}$ & (Jurado-Sanchez et al., 2015) \\
$\mathbf{Z r / r G O / N i / P t ~ t u b u l a r ~ m i c r o m o t o r s ~}$ & $\begin{array}{l}\text { Chemical warfare agents } \\
\text { rGO/Ni/Pt tubular micromotors }\end{array}$ & (Singh et al., 2015) \\
$\mathbf{r G O / P t ~ J a n u s ~ m i c r o m o t o r s ~}$ & Heavy metals & (Vilela et al., 2016) \\
$\mathbf{G O / P t}$ nanoparticles (NPs) rolled - up micromotors & Oil droplets & (Orozco et al. 2016) \\
\hline $\begin{array}{l}\text { Degradation of pollutants } \\
\text { Advanced oxidation }\end{array}$ & & (Baptista-Pires et al., 2018) \\
$\mathbf{r G O / P r u s s i a n}$ blue hydrogel micromotor & Azo dyes & \\
\hline
\end{tabular}


be created. Toxicity of nanoparticles and their biocompatibility have also to be considered (Ghika et al., 2018).

The reticulo-endothelial system (RES) is a part of the immune system composed of phagocytic cells. Macrophages and monocytes are located in spleen and in lymph nodes, while Kupffer cells are located in liver. The main role of this system is to eliminate old or foreign cells and create new cells for immune and inflammatory response. Tumor cells induce the infiltration of other cell types and instruct them (fibroblasts, endothelial cells and immune cells) in cell-contact dependent (paracrine, receptormediated) and contact independent manner (endocrine, cytokines and other signaling molecules) to establish a self-promoting and mutually selfreinforcing tumor microenvironment (TME) that promotes tumor progression (Conde et al., 2016). This system is active mainly in the elimination of larger nanoparticles. The smaller the particle, the longer time is needed to eliminate the particles from blood circulation. It was found that particles smaller than $200 \mathrm{~nm}$ are the ideal size for cancer treatment (Song et al., 2017). The lower limit of the size is derived from the ability to filter particles in the kidneys. Glomerular barrier transmits particles smaller than $6 \mathrm{~nm}$, while those larger than $8 \mathrm{~nm}$ will not pass through. Also, a healthy endothelium has an effective pore size of about $5 \mathrm{~nm}$; therefore, NMs smaller than this size will pass through into the extra-vassal spaces. The entry of foreign particles into a cell is blocked by three stage mechanism. Using opsonization, macrophages recognize foreign particles and absorb them via endocytosis, and the digestive enzymes try to break them down. If the particle is not biodegradable, it is removed by kidneys or stored in the reticulo-endothelial system (Barreto et al., 2011).

Degradation of NMs through RES is also linked to the polarity and charge of particles. This process is faster if the particles are more hydrophobic, which allows for better adsorption of blood proteins on their surface. Also surface charge affects the elimination of NMs; neutral particles or particles with low charge are removed immediately. Positively charged particles are not specifically linked to the cells, whereas the negative charge attracts phagocytes in liver. It has been proved that zeta potential of a particle higher than $\pm 30 \mathrm{mV}$ prevents its agglomeration in a model suspension (Barreto et al., 2011).

\section{Conclusions}

The article briefly summarizes the general characteristics of NMs, especially their properties with which they penetrate into the environment (water, soil). Furthermore, individual members of the graphene family, including porous carbon (biochar), are described. The main characteristics, preparation, and the new eco-friendly applications of carbon based NMs as self-propelled micromotors are introduced. NMs have become an important part of medical research combining diagnosis and therapy into one system, which provides new possibilities in treatment of diseases such as cancer.

\section{Acknowledgements}

This work was supported by the grant scheme for supporting young researchers at STU in Bratislava: "Nanomateriály - inovatívny postup odstrañovania mikropolutantov" and the grant scheme for supporting excellent teams of young researchers at STU in Bratislava: "Mikropolutanty a rezistentné kmene baktérii ich monitoring a možnosti použitia inovatínnych postupov na ich odstránenie - nanomateriály a železany”. The publication was written within the Student grant competition "Preparation of New Carbon - based Nano - materials and their Modifications on Nano - metal Composites Using New Ways and Monitoring of Nano - material Relation to the Natural Environment" - project number SP2017/95. This work was also supported by VEGA 1/0343/19.

\section{References}

Agharkar M, Kochrekar S, Hidouri S, Azeez MA (2014) Mater Res Bull 59: 323.

Ahmed F, Rodrigues DF (2013) J Hazard Mater 256-257: 33.

Anjum NA, Singh N, Singh MK, Sayeed I, Duarte AC, Pereira E, Ahmad I (2014) Sci Total Environ 472: 834.

Bakand S, Hayes A, Dechsakulthorn F (2012) Inhalation Toxicol 24: 125 .

Baptista-Pires L, Orozco J, Guardia P, Merkoci A (2018) Small (Weinheim an der Bergstrasse, Germany) 14.

Barreto JA, O’Malley W, Kubeil M, Graham B, Stephan H, Spiccia L (2011) Adv Mater 23: H18.

Baun A, Sayre P, Steinhäuser KG, Rose J (2017) NanoImpact 8: 1 .

Begum P, Ikhtiari R, Fugetsu B (2011) Carbon 49: 3907.

Borm PJ, Robbins D, Haubold S, Kuhlbusch T, Fissan H, Donaldson K, Schins R, Stone V, Kreyling W, Lademann J, Krutmann J, Warheit D, Oberdorster E (2006) Part Fibre Toxicol 3: 11.

Brandeburová P, Bírošová L, Vojs M, Kromka A, Gál M, Tichý J, Híveš J, Mackulak T (2017) Monatsh Chem Chemical Monthly 148: 525.

Calvaresi M, Quintana M, Rudolf P, Zerbetto F, Prato M (2013) Chem Phys Chem 14: 3447.

Chabot V, Higgins D, Yu A, Xiao X, Chen Z, Zhang J (2014) E Environ Sci 7: 1564.

Chartarrayawadee W, Moulton SE, Too CO, Kim BC, Yepuri R, Romeo T, Wallace GG (2013) J Appl Electrochem 43: 865.

Chen L, Hu P, Zhang L, Huang S, Luo L, Huang C (2012) Sci China Chem 55: 2209. 
Chen M, Sun Y, Liang J, Guangming Z, Li Z, Tang L, Zhu Y, Jiang D, Song B (2019) Environ Int 126: 690-698.

Chien CT, Li SS, Lai WJ, Yeh YC, Chen HA, Chen IS, Chen LC, Chen KH, Nemoto T, Isoda S, Chen M, Paredes JI, Fernández-Merino MJ, Villar-Rodil S, SolísFernández P, Guardia L, García R, Martínez-Alonso A, Tascón JMD (2013) Preparation of graphene and graphene-metal nanoparticle hybrids with enhanced catalytic activity by reduction of graphite oxide with efficient natural bioreductants Paper presented at the Imagine Nano, Bilbao Spain.

Chng ELK, Pumera M (2013) Chemi - A Europ J 19: 8227.

Chua CK, Pumera M (2013) Chem Soc Rev 42: 3222.

Chung C, Kim YK, Shin D, Ryoo SR, Hong BH, Min DH (2013) Acc Chem Res 46: 2211.

Conde J, Arnold CE, Tian F, Artzi N (2016) Mater Today 19: 29.

Donaldson K, Stone V, Tran CL, Kreyling W, Borm PJA (2004) Occupational Environ Med 61: 727.

Duarte, Armando C. In: Cachada A, Rocha-Santos T (eds) Soil Pollution. Academic Press, pp 161. doi: 10.1016/B978-0-12-849873-6.00007-8.

Durnev AD, Lapitskaya AS (2013) Russ J Genet: Applied Research 3: 388.

Fakhri A (2017) J Saudi Chem Soc 21: S52.

Fernández-Merino MJ, Guardia L, Paredes JI, VillarRodil S, Solís-Fernández P, Martínez-Alonso A, Tascón JMD (2010) J Phys Chem C 114: 6426.

Freixa A, Acuña V, Sanchís J, Farré M, Barceló D, Sabater S (2018) Sci Total Environ 619-620: 328.

Fujita T, Eda G, Yamaguchi H, Chhowalla M, Chen CW (2012) Angew Chem Int Ed Engl 51: 6662.

Gao M, Zhang Z, Lv M, Song W, Lv Yu (2018) Ecotoxicol and Environ Saf 148: 261-268.

Garcia IL (2017) Antimicrobial activity of graphene and its viability. Degree final project. University of Barcelona pp 34.

Gkika DA, Magafas L, Cool P, Braet J (2018) Toxicology 393: 83.

Gopalakrishnan I, Sugaraj Samuel R, Sridharan K (2018) Nanomaterials-Based Adsorbents for Water and Wastewater Treatments. In: Sridharan K (ed) Emerging Trends of Nanotechnology in Environment and Sustainability: A Review-Based Approach. Springer International Publishing, Cham, pp 89. doi: 10.1007/978-3-319-71327-4_11.

Guo X, Mei N (2014) J Food and Drug Anal 22: 105.

Hao J, Yang W, Zhang Z, Tang J (2015) Nanoscale 7: 10498.

Hu Y, Sun X (2013) Chemically Functionalized Graphene and Their Applications in Electrochemical Energy Conversion and Storage. In: Aliofkhazraei M (ed) Ad Graphene Sci. InTech, Rijeka, p Ch. 07. doi: $10.5772 / 55666$.

Hussain S, Boland S, Baeza-Squiban A, Hamel R, Thomassen LC, Martens JA, Billon-Galland MA, Fleury-Feith J, Moisan F, Pairon JC, Marano F (2009) Toxicology 260: 142.

Jamieson T, Bakhshi R, Petrova D, Rocock R, Imani M, Seifalian AM (2007) Biomaterials 28: 31, 4717-4732.

Jastrzebska AM, Kurtycz P, Olszyna AR (2012) J Nanopart Res 14: 1320.

Jia H-R, Zhu Y-X, Duan Q-Y, Chen Z, Wu F-G (2019) J of Control Rel 311-312, 301-318.
Ju H (2018) Appl Mater Today 10: 51.

Jurado-Sanchez B, Sattayasamitsathit S, Gao W, Santos L, Fedorak Y, Singh VV, Orozco J, Galarnyk M, Ramesha GK, Vijaya Kumara A, Muralidhara HB, Sampath S (2011) J Colloid Interface Sci 361: 270.

Jurado-Sánchez B, Wang J (2018) Environ Sci: Nano 5: 1530.

Kabiri S, Tran DN, Altalhi T, Losic D (2014) Carbon 80: 523.

Krishnakumar S, Rajalakshmi AG, Balaganesh B, Manikandan P, Vinoth C, Rajendran V (2014) Int J Ad Res 2: 933

Kyzas GZ, Deliyanni EA, Matis KA (2014) J Chem Technol Biotechnol 89: 196.

Lalwani G, D’Agati M, Khan AM, Sitharaman B (2016) Adv Drug Delivery Rev 105: 109.

Lee J, Lee B, Shin D, Kwak SS, Bahk JD, Lim CO, Yun DJ (2002) Mol Cells 13(3): 407-412.

Lee JW, Hall AS, Kim J-D, Mallouk TE (2012) Chem Mater 24: 1158.

Li J, Rao J, Pu K (2018) Biomaterials 155: 217.

Lim SY, Shen W, Gao Z (2015) Carbon quantum dots and their applications. Chem. Soc. Rev. 44 (1), 362-381.

Lin J, Chen X, Huang P (2016) Adv Drug Delivery Rev 105: 242.

Liu Y, Tourbin M, Lachaize S, Guiraud P (2014) Powder Technol 255: 149.

Loureiro S, Tourinho PS, Cornelis G, Van Den Brink NW, Díez-Ortiz M, Vázquez-Campos S, Pomar-Portillo V, Svendsen C, Van Gestel CAM (2018) Chapter 7 Nanomaterials as Soil Pollutants A2.

Mackulak T, Vojs M, Grabic R, Golovko O, Staňová AV, Birošová L, Medvedová A, Híveš J, Gál M, Kromka A, Hanusová A (2016) Monatsh Chem - Chemical Monthly 147: 97.

Martinéz-Paz P, Negri V, Esteban-Arranz A, MartínezGuitarte JL, Ballesteros P, Morales M (2019) Aquat Toxicol 209: 42-48.

Molaei MJ (2019b) A review on nanostructured carbon quantum dots and their applications in biotechnology, sensors, and chemiluminescence. Talanta 196, 456-478.

Molaei MJ (2019a) Carbon quantum dots and their biomedical and therapeutic applications: a review. RSC Adv. 9 (12), 6460-6481.

Molaei MJ (2020) The optical properties and solar energy conversion applications of carbon quantum dots: A review. Sol. Energy 196, 549-566.

Mesarič T, Sepčič K, Piazza V, Gambardella C, Garaventa F, Drobne D, Faimali M (2013) Chem Ecol 29: 643

Miners SA, Rance GA, Khlobystov AN (2016) Chem Soc Rev 45: 4727.

Moon J, Kwak JI, An Y-J (2019) Chemosphere 215: $50-56$.

Nam S-H, An Y-J (2019) Ecotoxicol and Environ Saf 168: 388-393.

Notarianni M, Jinzhang L, Vernon K, Motta N (2016) Beilstein J of Nanotechnol 7, 149-196.

Oladipo AA, Ifebajo AO (2018) J Environ Manage 209: 9.

Orozco J, Mercante LA, Pol R, Merkoçi A (2016) J Mater Chem A 4: 3371.

Pan Y, Liu X, Zhang W, Liu Z, Zeng G, Shao B, Liang Q, He Q, Yuan X, Huang D, Chen M (2020) Appl. Cat. B: Environ 265: 118579.

Park J, Yan M (2013) Acc Chem Res 46: 181. 
Paulchamy B, Arthi G, Lignesh B (2015) J Nanomed Nanotechnol 6: 1.

Pochkaeva EI, Podolsky NE, Zakusilo DN, Petrov AV, Charykov NA, Vlasov TD, Penkova AV, Vasina LV, Murin IV, Sharoyko VV, Semenov KN (2020) Prog Solid State Chem 57: 100255.

Roacho Perez JA, Gallardo Blanco HL, Sanchez Dominguez M, Garcia Casillas PE, Chapa Gonzalez C, Sanchez Dominguez CN (2018) Mol Med Rep 17: 1413.

Roupcová P (2017) Monitorování ekotoxicity u nanočástic na bázi uhlíku. Thesis for dissertation work, Technical University of Ostrava, Ostrava.

Roupcová P, Friedrichová R, Klouda K, Weisheitelová M, Perdochová M (2017) Biochar Modification, Thermal Stability and Toxicity of Products Modification. TRANSACTIONS of the VŠB - Technical University of Ostrava, Safety Engineering Series, vol 12. doi: 10.1515/tvsbses-2017-0012.

Roupcová P, Klouda K (2017) Hybrid Compounds based on Graphene Oxide and their Compounds with Metals. Paper presented at the Nanocon 2017, Brno, Czech Republic.

Roupcová P, Klouda K, Pavlovský J, Weisheitelová M (2017) DEStech Transactions on Engineering and Technology Research.

Roupcová P, Kubátová H, Klouda K, Lepík P (2016) Phytotoxicological Tests - Applications of Foils Based on Graphene (Graphene Oxide). TRANSACTIONS of the VŠB - Technical University of Ostrava, Safety Engineering Series, vol 11. doi: 10.1515/ tvsbses-2016-0011.

Sanchez VC, Jachak A, Hurt RH, Kane AB (2012) Chem Res Toxicol 25: 15.

Saunders DS, Gillanders SW, Lewis RD (1994) J Insect Physiol 40(11): 957-968.

Sen A, Ibele M, Hong Y, Velegol D (2009) Faraday Discuss 143: 15 .

Seabra AB, Paula AJ, de Lima R, Alves OL, Duran N (2014) Chem Res Toxicol 27: 159.

Schmidt H, Wilson K (2014) the Biochar J.

Shahil KM, Balandin AA (2012) Solid State Commun 152: 1331 .

Shanmugharaj AM, Yoon JH, Yang WJ, Ryu SH (2013) J Colloid Interface Sci 401: 148.

Sharma A, Anghore D, Awasthi R, Kosey S, Jindal S, Gupta N, Raj D, Sood R (2015) World J of Pharm and Pharm Sci 4, 1088-1113.

Singh VV, Martin A, Kaufmann K, DS de Oliveira S, Wang J (2015) Chem Mater 27: 8162.

Song W, Musetti SN, Huang L (2017) Biomaterials 148: 16.

Stanković DM, Ognjanović M, Fabian M, Švorc L', Mariano JFML, Antić B (2017) Anal Biochem 539: 104.
Svítková J, Ignat T, Švorc L', Labuda J, Barek J (2016) Crit Rev Anal Chem 46: 248.

Sun M, Wang G, Li X, Li C (2014) J Power Sources 245: 436.

Tabei Y, Fukui H, Nishioka A, Hagiwara Y, Sato K, Yoneda T, Koynama T, Horie M (2019) Sci Rep 9: 2224.

Terrones H, Lv R, Terrones M, Dresselhaus MS (2012) Rep Prog Phys 75: 062501.

Theng BK, Yuan G (2008) Elements 4: 395.

Tiede K, Boxall ABA, Tear SP, Lewis J, David H, Hassellöv M (2008) Food Addit Contam: Part A 25: 795.

Tratnyek PG, Johnson RL (2006) Nano Today 1: 44.

Vilela D, Parmar J, Zeng Y, Zhao Y, Sánchez S (2016) Nano Lett 16: 2860.

Wang D, Yang G, Ma Q, Wu M, Tan Y, Yoneyama Y, Tsubaki N (2012) ACS Catal 2: 1958.

Wang G, Qian F, Saltikov CW, Jiao Y, Li Y (2011) Nano Res 4: 563.

Wang J (2015) Small (Weinheim an der Bergstrasse, Germany) 11: 499.

Wang L, Xiong Q, Xiao F, Duan H (2017) Biosens Bioelectron 89: 136.

Weber K, Quicker P (2018) Fuel 217: 240.

Wei D, Li B, Huang H, Luo L, Zhang J, Yang Y, Guo J, Tang L, Zeng G, Zhou Y (2018) Chemosphere.

Woo S, Kim Y-R, Chung TD, Piao Y, Kim H (2012) Electrochim Acta 59: 509.

Xu Z, Sun H, Zhao X, Gao C (2013) Adv Mater 25: 188.

Yao Y, Wu F (2015) Nano E 17: 91.

Yoo BM, Shin HJ, Yoon HW, Park HB (2014) J Appl Polym Sci 131: n/a.

Zhang L, Jiang J, Holm N, Chen F (2014) J Appl Electrochem 44: 1145.

Zhang W, Li X, Yang Z, Tang X, Ma Y, Li M, Hu N, Wei H, Zhang Y (2016) Nanotechnology 27: 265703.

Zhang X, Huang Y, Wang Y, Ma Y, Liu Z, Chen Y (2009) Carbon 47: 334.

Zhang Y, Ren L, Wang S, Marathe A, Chaudhuri J, Li G (2011) J Mater Chem 21: 5386.

Zhao J, Wang Z, White JC, Xing B (2014) Environ Sci Technol 48: 9995.

Zhou X, Laroche F, Lamers GEM, Torraca V, Voskamp P, Lu T, Chu F, Spaink HP, Abrahams JP, Liu Z (2012) Nano Res 5: 703.

Zhu S, Tang S, Zhang J, Yang B (2012) Chem Commun (Camb) 48: 4527.

Zuo P et al. (2016) A review on syntheses, properties, characterization and bioanalytical applications of fluorescent carbon dots. Microchim. Acta 183 (2), $519-542$. 